\title{
Assessment of Morphometric Parameters in Baitarani Basin using Remote Sensing and GIS
}

\author{
N. Sahoo*, B. Panigrahi, J.C. Paul and B.P. Behera \\ Soil and Water Conservation Engineering, CAET, OUAT, Bhubaneswar, India \\ *Corresponding author
}

\section{A B S T R A C T}

Morphometric analysis is and important and crucial parameter in watershed

Keywords

Remote sensing,

DEM, GIS,

Morphometric

parameters, Baitarani

basin

Article Info

Accepted:

15 July 2019

Available Online:

10 August 2019 development and management programme. The present study is conducted on Baitarani basin upto Anandapur covering $8603.7 \mathrm{~km}^{2}$ area. The morphometric analysis of the study area is done in GIS platform. Watershed delineation is done from ASTER DEM. In this paper three aspects of morphometric analysis i.e. linear, areal and relief aspects are carried out and pertinent results are discussed. The highest order stream of the area is found to be $5^{\text {th }}$ order. The mean bifurcation ratio and length of overland flow of the study area are 4.4 and $2.28 \mathrm{~km}$, respectively which indicate high surface runoff in the basin and late youth stage of geomorphic development of the basin. The drainage density, stream frequency and drainage texture are calculated as $0.219 \mathrm{~km} / \mathrm{km}^{2}, 0.039 \mathrm{~km}^{-2}$ and 0.409 $\mathrm{km}^{-1}$, respectively. Ruggedness value is 0.258 .

\section{Introduction}

Morphometric analysis is the process of measurement and mathematical analysis of the configuration of the earth's surface, shape and dimension of its landforms (Clarke, 1966). The morphometric analysis could be achieved through measurement of linear, aerial and relief aspects of basin (Horton, 1945). This provides a quantitative description of the drainage system which is an important aspect of the characterization of watersheds (Strahler, 1964). Morphometric analysis measures the 3 dimensional geometry of landform and has traditionally been applied to watershed, drainages, hill slopes, and other group of terrain features (Barber, 2005) The morphological characteristics at the watershed scale, may contain important information regarding its formation and development because, all hydrologic and geomorphic processes occur within the watershed (Singh, 1992). Quantitative morphometric characterization of a drainage basin is considered to be the most appropriate method for the proper planning and management of watershed, because it enables to understand the relationship among different aspects of the 
drainage pattern of the basin and also to make a comparative evaluation of different drainage basins, developed in various geologic and climatic regimes (Pingale et al., 2012). A drainage basin represents a natural hydrological entity which enables surface runoff to a defined channel, ravine, stream or river at a particular point (Chopra et al., 2005). Drainage network is the system of streams which transport runoff, sediment and other material from a drainage area (Bowlekar et al., 2019).

The morphometric analysis consists of linear, aerial and relief aspects. This is an important tool for understanding the topographic situation and hydrological condition of watershed. Quantitative evaluation of geomorphological parameters of a basin is very much important in modelling runoff (Singh, 1994). Morphological parameters within certain range of values directly indicate the runoff generation and erosion hazard of a watershed. Apart from rainfall, soil, vegetation and slope, the quantitative hydromorphological characteristics also affect the stream flow hydrograph, run-off volume, runoff intensity and peak flow.

Computation of morphological parameters in GIS environment using remote sensing has proved to be less tedious, fast, most updated and accurate and made best spatial representation of topographic situations (Singh et al., 2013). In recent years, the importance of remote sensing technology for geomorphological studies has increased because, it is not only cost effective, but also reliable and timely (Magesh et al.,2012). Integration of Remote Sensing (RS) and Geographic Information System (GIS) technologies have been utilized worldwide to identify and examine changes in the landscape and the consequential environmental impacts like gully erosion, flooding, etc. RS and GIS techniques have also proven to be capable tools in the delineation, characterization and morphometric analysis of drainage basins worldwide (Paulinus et al., 2016).

The GIS technology has the ability to capture, store, manipulate, analyze, and visualize the geo-referenced data which is further used. DEMs (Digital Elevation Model) can be used to derive flow networks and then automatically generate watershed boundaries for given outlet points using GIS technology. Therefore, an essential component to watershed delineation is a hydrologically sound DEM of the land area of interest (Julia et al., 2007).

Raju and Kumar (2011) classified microwatersheds based on morphological characteristics. They used three classification techniques, namely, K-means Cluster Analysis (KCA), Fuzzy Cluster Analysis (FCA) and Kohonen Neural Networks (KNN) to group 25 micro watersheds of Kherthal watershed, Rajasthan. They classified micro-watersheds into homogeneous groups for formulating the basis for suitable conservation and management practices. Choudhari et al., (2014) studied morphometric analysis of Kharlikani watershed in Odisha using spatial information technology. By using GIS techniques, they created the basin model map, watershed network, land slope map, land use map and drainage network map. They also calculated various morphometric parameters of the watershed. The study revealed that the watershed was elongated in nature and had low drainage density.

Satish and Vajrappa (2014) calculated the morphological parameters through ASTERDEM using GIS and RS techniques. They studied Hosakote watershed of Dakshina Pinakini River Basin, Karnataka, India. They studied the groundwater potential zone and sites for groundwater recharge using morphological analysis. 
Gajbhiye (2015) analysed the morphometry of Shakkar River Catchment using RS and GIS. He delineated the catchment and preparation of drainage map from geo-coded Digital Elevation Model (DEM) using Arc view 3.1 power GIS software. He found that basin structure was dendritic covering area of 2220 sq.km that produced high surface runoff with low infiltration rates. He concluded that conventional methods of morphometric analysis was time consuming, tiresome and error prone, while use of GIS technique was more reliable and accurate in estimation of parameters of watersheds. Sutariya et al., (2015) studied the morphometric analysis of Dhadhar River Basin, Gujarat. Development of morphometric techniques was a great advance within the quantitative description of basin in form of the pure mathematics and its network that helps in characterizing the drainage network and examining the impact of variables like lithology, rock structure, rain etc. The morphometric analysis clearly indicated some relations among the attributes of the morphometric parameters of the basin and would help to grasp their role indicating the surface of the region.

Afreeda and Kannan (2018) determined the watershed morphological parameters using Remote Sensing and GIS. They studied the morphological parameters of three sub watersheds of Nilgiris district of Tamil Nadu. Remote Sensing (RS) coupled with Geographical Information System (GIS) technique had proved to be an efficient tool in drainage delineation and their study for morphometric analysis. They used four different DEM sources viz., Toposheet, ASTER, SRTM and Cartosat data for delineating watershed boundary. Geographical information system for evaluation of linear aspects of morphometric parameters was carried out. They concluded that the use of geospatial technologies was more effective in comparison with the conservative approach in terms of time taken and output product.

\section{Materials and Methods}

\section{Study area}

The study area for this research work is Baitarani basin upto Anandapur. The Baitarani river is one of the major rivers of Odisha. It originates from Guptaganga hills near Gonasika village in Kendujhar district of Odisha. The basin spreads over latitude of $20^{\circ}$ $35^{\prime}$ to $22^{0} 15^{\prime} \mathrm{N}$ and longitude of $85^{\circ} 10^{\prime}$ to $87^{\circ} 03^{\prime}$ E. Anadapur gauging station has latitude of $21^{0} 12^{\prime} 34^{\prime \prime}$ Nand longitude of $86^{0} 07^{\prime} 23^{n}$ E. The major portion of the river basin lies in the state of Odisha, while a smaller part of the upper reach lies in Jharkhand state. The river travels about 360 $\mathrm{km}$ to drain water in the Bay of Bengal. Before draining into the Bay of Bengal, the river flows in a northern direction for about 80 $\mathrm{km}$ and then takes an abrupt right turn near Champua and flows in a south easterly direction and joins to the deltaic area of river Brahmani. The total drainage area of the basin is over $14,000 \mathrm{~km}^{2}$. The Baitarani basin covers most of area of Kendujhar, Bhadrak, Mayurbhanj and Balasore districts. The river has total 65 tributaries out of which 35 join from the left side and 30 join from the right side. The main tributaries of Baitarani River are Budhi, Kanjori, Ambajhara, Mushal, Kusei, Salandi. Figure 1 shows the location map of study area.

The Baitarani river basin mainly falls within the sub-tropical monsoon climate zone. The annual normal rainfall varies from $1250 \mathrm{~mm}$ to $1500 \mathrm{~mm}$ over the Baitarani basin. About $80 \%$ of the annual normal rainfall occurs during the 4 months of south-west monsoon season (June to September). The coefficient of variation of annual rainfall is about $20 \%$, which indicates that the rainfall in the region is fairly dependable (HP, 1998).

The study area has maximum temperature of 
$47^{0} \mathrm{C}$ in summer and minimum temperature of $9^{0} \mathrm{C}$ in winter. The maximum relative humidity is $83.08 \%$ and it is observed in the month of August. The minimum relative humidity is $39.63 \%$ which it is observed in the month of April. The maximum wind speed is $70 \mathrm{~km} / \mathrm{h}$ and minimum wind speed is $7 \mathrm{~km} / \mathrm{h}$. The cloud cover is observed to be maximum in the month of June and July and minimum in the month of December and January (Anonymous, 2011).

The drainage pattern of Baitarani river basin (central plateau) is dendrite type and flash flood is a natural character of such type of drainage pattern. The major part of basin is covered with agricultural land accounting to $52 \%$ of the total area and $3 \%$ of the basin is covered by water bodies. The upper catchment of Baitarani is full of hillocks (Anonymous, 2011).

A large number of drainage lines are present which allow the run off to rush into the main river with greater force in very short span of time. Baitarani is a highly meandering river. In meandering channels, the flow is highly turbulent and forms eddy currents which very often leads to sudden overflow of the embankments causing inundation of surrounding areas. There is heavy mining activities and practices of shifting cultivation in the upper catchment. Therefore, a large quantity of sediments is added to the river during monsoon seasons. The most flood affected blocks in Baitarani basin are Anandapur, Dasarathpur, Korei, Bari, Jajpur, Binjharpur and Rajkanika.

\section{Watershed morphometric characteristics}

Watershed morphometric characteristics contains linear aspects, areal aspects and relief aspects. The watershed delineation and stream network preparation were done in GIS platform from ASTER DEM having resolution $30 \mathrm{~m}$.
Other morphometric parameters were calculated manually.

\section{Linear aspects of morphometric parameters}

In this study, various linear aspects of the basin such as stream number, stream order, stream length, mean stream length, bifurcation ratio, and stream length ratio were calculated. These parameters and the formula to calculate them are described in Table 1.

\section{Areal aspects of morphometric parameters}

The areal aspects of the watershed like drainage density, stream frequency, drainage intensity, drainage texture, infiltration number, texture ratio, elongation ratio, circulatory ratio, form factor, length of overland flow and channel maintenance factor were calculated as described in Table 2.

\section{Relief aspects of morphometric parameters}

Relief aspects of a drainage basin replicate the topographical gradient characteristics of the basin and give a bird's eye view of the whole area (Pophare and Balpande, 2014).

The relief aspects of watershed such as total relief, relief ratio, relative relief and ruggedness number were computed by the method as described in Table 3.

\section{Results and Discussions}

The different morphometric parameters of the study basin were calculated as described in materials and method section and are presented in Table 4.

\section{Linear aspects}

\section{Stream order $(\mathbf{u})$}

A stream segment with no tributaries is called first order stream (Strahler, 1964). When two 
first orders come together they form a second order stream and so forth. When a higher order stream joins with a lower order stream, the order of resulting stream is the same as that of the higher order stream. In the study area, highest order stream is found to be $5^{\text {th }}$ order. The stream network of the study area is shown in figure 2 . In the highest order stream segment, all discharge of runoff and sediment pass.

\section{Stream length (Lu)}

Stream length of different order streams are shown in Table 4. The length of the streams of $1^{\text {st }}, 2^{\text {nd }}, 3^{\text {rd }}, 4^{\text {th }}$ and $5^{\text {th }}$ order stream are 908.5 , 464.3, 300.3, 108.3 and $106.5 \mathrm{~km}$, respectively. It is observed that length of stream segments is highest in first order streams and decreases as the stream order increases. So, it is assumed that the basin is subjected to erosion and some areas of the basin are characterized by variation in lithology and topography (Singh and Singh, 1997).

\section{Stream number $\left(\mathbf{N}_{\mathrm{u}}\right)$}

From Table 4 and Figure 2, it is seen that the number of streams for $1^{\text {st }}$ order, $2^{\text {nd }}$ order, $3^{\text {rd }}$ order, $4^{\text {th }}$ order and $5^{\text {th }}$ order were $270,58,13$, 2 and 1, respectively. The number of stream is highest for $1^{\text {st }}$ order stream and lowest for $5^{\text {th }}$ order stream. It is observed that the number of stream decreases as the order of stream increases.

\section{Stream length ratio $\left(\mathbf{R}_{\mathbf{L}}\right)$}

From Table 4, it is observed that the stream length ratios are $0.51,0.64,0.36$ and 0.98 for $2^{\text {nd }}, 3^{\text {rd }}, 4^{\text {th }}$ and $5^{\text {th }}$ order streams, respectively. If there is a change of stream length ratio from one order to another order, it indicates their late youth stage of geomorphic development
(Singh and Singh, 1997). The variation in stream length ratio is due to change in slope and topography (Moharir and Pande, 2014).

\section{Bifurcation ratio $\left(\mathbf{R}_{\mathbf{b}}\right)$}

As shown in Table 4, the bifurcation ratio for $1^{\text {st }}, 2^{\text {nd }}, 3^{\text {rd }}$ and $4^{\text {th }}$ order streams are $4.65,4.46$, 6.5 and 2, respectively. The mean bifurcation ratio of the study area is 4.4 , which indicates that geological structures are less disturbing the drainage pattern and also the watershed is less elongated and may result in high peak of runoff rate (Strahler, 1964). Strahler (1957) confirmed that, bifurcation ratio shows only a small variation for different regions with different environments, except where powerful geological control dominates.

\section{Areal aspects}

\section{Drainage density (D)}

The drainage density is calculated as 0.219 $\mathrm{km} / \mathrm{km}^{2}$. Drainage densities range from less than $5 \mathrm{~km} / \mathrm{km}^{2}$ in areas, where the slopes are gentle and have permeable bedrock. Similarly larger values i.e., more than $500 \mathrm{~km} / \mathrm{km}^{2}$ are found in upland areas where rocks are impermeable and steep slopes. (Sharma, 2014). The drainage density of the study area indicate that areas are highly permeable subsoil material, dense vegetation, low relief and coarse drainage texture (Sethupathi et al., 2011).

\section{Stream Frequency $\left(\mathbf{F}_{\mathrm{s}}\right)$}

Stream frequency is calculated as $0.039 \mathrm{~km}^{-2}$. Stream frequency exhibits positive correlation with drainage density in the watershed, which indicates an increase in stream population with respect to increase in drainage density (Sharma, 2014). 
Table.1 Formula to calculate linear aspects of morphometric parameters

\begin{tabular}{|c|c|c|}
\hline Linear aspects & Formula & Reference \\
\hline Stream order, $\mathrm{U}$ & Hierarchical rank & Strahler (1964) \\
\hline Stream length $(\mathrm{km}), \mathrm{L}_{\mathbf{u}}$ & Length of the stream segment & Horton (1945) \\
\hline Stream number, $\mathbf{N}_{\mathbf{u}}$ & Number of stream segments & Strahler (1964) \\
\hline Mean stream length, $\mathrm{L}_{\mathrm{sm}}$ & $\begin{array}{l}L=\frac{L_{u}}{N_{u}} \\
\text { Where } \mathrm{L}_{\mathrm{u}}=\text { Total stream length of } \\
\text { order ' } \mathrm{u} \text { ' } \\
\mathrm{N}_{\mathrm{u}}=\text { Total no. of stream segments } \\
\text { of order ' } \mathrm{u} \text { ' }\end{array}$ & Strahler (1964) \\
\hline Bifurcation ratio, $\mathbf{R}_{b}$ & $\begin{array}{l}R_{b}=\frac{N_{u}}{N_{u+1}} \\
\text { Where } \mathrm{Nu}=\text { Total no. of stream } \\
\text { segments of order ' } \mathrm{u} \text { ' } \\
\text { Nu+1 = Number of segments of } \\
\text { the next higher order }\end{array}$ & Schumm (1956) \\
\hline $\begin{array}{l}\text { Mean bifurcation ratio, } \\
\mathbf{R}_{\mathrm{bm}}\end{array}$ & $\begin{array}{l}\mathrm{R}_{\mathrm{bm}}=\text { Average of bifurcation ratios } \\
\text { of all orders }\end{array}$ & Strahler (1957) \\
\hline Stream length ratio, $\mathbf{R}_{\mathbf{L}}$ & $\begin{array}{l}R_{L}=\frac{L_{u}}{L_{u-1}} \\
\mathrm{~L}_{\mathrm{u}}=\text { Total stream length of order } \\
\text { ' } \mathrm{u} \text { ' } \\
\mathrm{L}_{\mathrm{u}-1}=\text { Total stream length of its } \\
\text { next lower order }\end{array}$ & Horton (1945) \\
\hline
\end{tabular}


Table.2 Formula to calculate areal aspects of morphometric parameters

\begin{tabular}{|c|c|c|}
\hline Areal aspects & Formula & Reference \\
\hline $\begin{array}{l}\text { Drainage } \\
\text { density }\left(\mathbf{k m} / \mathrm{km}^{2}\right), \text { D }\end{array}$ & $\begin{array}{l}D=\frac{L_{u}}{A} \\
\text { Where Lu = Total stream length of } \\
\text { order }(\mathrm{km}) \\
\mathrm{A}=\text { Area of the basin }\left(\mathrm{km}^{2}\right)\end{array}$ & Horton (1945) \\
\hline Stream frequency, $F_{s}$ & $\begin{array}{l}F_{S}=\frac{N_{u}}{A} \\
\text { Where } \mathrm{Nu}=\text { Total no. of streams of all } \\
\text { orders } \\
\mathrm{A}=\text { Area of the basin }\left(\mathrm{Km}^{2}\right)\end{array}$ & Horton (1945) \\
\hline Drainage texture, $\mathbf{R}_{t}$ & $\begin{array}{l}R_{t}=\frac{N_{u}}{P} \\
\text { Where } \mathrm{Nu}=\text { Total no. of streams of all } \\
\text { orders } \\
\mathrm{P}=\text { Basin Perimeter }(\mathrm{km})\end{array}$ & Horton (1945) \\
\hline Elongation ratio, $\mathbf{R}_{\mathrm{e}}$ & $\begin{array}{l}R_{e}=\frac{\sqrt{\left(\frac{4 \times A}{\pi}\right)}}{L_{b}} \\
\text { Where A = Area of the Basin }\left(\mathrm{km}^{2}\right) \\
\mathrm{L}_{\mathrm{b}}=\text { Basin length }(\mathrm{km})\end{array}$ & Schumm (1956) \\
\hline Circularity ratio, $\mathbf{R}_{\mathrm{c}}$ & $\begin{aligned} R_{C} & =\frac{(4 \times \pi \times A)}{P^{2}} \\
P i & =\text { 'Pi'value i.e. } 3.14 \\
\text { A } & =\text { Area of the Basin }\left(\mathrm{km}^{2}\right) \\
\mathrm{P} & =\text { Perimeter }(\mathrm{km})\end{aligned}$ & Miller (1953) \\
\hline Form Factor, $\mathbf{F}_{\mathrm{f}}$ & $\begin{array}{l}F_{f}=\frac{A}{\left(L_{b}\right)^{2}} \\
\text { Where A = Area of the Basin }\left(\mathrm{km}^{2}\right) \\
\mathrm{L}_{\mathrm{b}}^{2}=\text { Square of Basin Length }(\mathrm{km})\end{array}$ & Horton (1945) \\
\hline $\begin{array}{l}\text { Length of overland } \\
\text { flow, } L_{g}\end{array}$ & $L_{g}=\frac{1}{2 D}$ & Horton (1945) \\
\hline $\begin{array}{l}\text { Channel maintenance } \\
\text { factor, } C_{m}\end{array}$ & $\begin{array}{l}C_{m}=\frac{1}{D} \\
\text { Where } \mathrm{D}=\text { Drainage density }\end{array}$ & Schumm (1956) \\
\hline
\end{tabular}


Table.3 Formula to calculate relief aspects of morphometric parameters

\begin{tabular}{|l|l|l|}
\hline Relief aspects & Formula & Reference \\
\hline Total relief, $\mathbf{H}$ & $\begin{array}{l}\text { Maximum vertical distance between the } \\
\text { lowest (outlet) and highest (divide) } \\
\text { points on the valley floor of a watershed }\end{array}$ & Schumm (1956) \\
\hline Relief ratio, $\mathbf{R}_{\mathbf{h}}$ & $\begin{array}{l}R_{h}=\frac{H}{L_{b}} \\
\text { Where } \mathrm{H}=\text { Total relief of the basin }(\mathrm{km}) \\
\mathrm{L}_{\mathrm{b}}=\mathrm{Basin} \text { length }(\mathrm{km})\end{array}$ & \\
\hline Relative relief, $\mathbf{R}_{\mathbf{p}}$ & $\begin{array}{l}R_{p}=\frac{H}{P} \\
\text { Where } \mathrm{H}=\text { Total relief } \\
\mathrm{P}=\text { Basin perimeter }\end{array}$ & Melton (1958) \\
\hline $\begin{array}{l}\text { Ruggedness } \\
\text { number, } \mathbf{R}_{\mathbf{n}}\end{array}$ & $\begin{array}{l}R_{n}=H \bullet D \\
\text { Where } \mathrm{D}=\text { Drainage density } \\
\mathrm{H}=\text { Total relief of the basin, } \mathrm{km}\end{array}$ & Strahler (1964) \\
\hline
\end{tabular}

Fig.1 Location map of study area

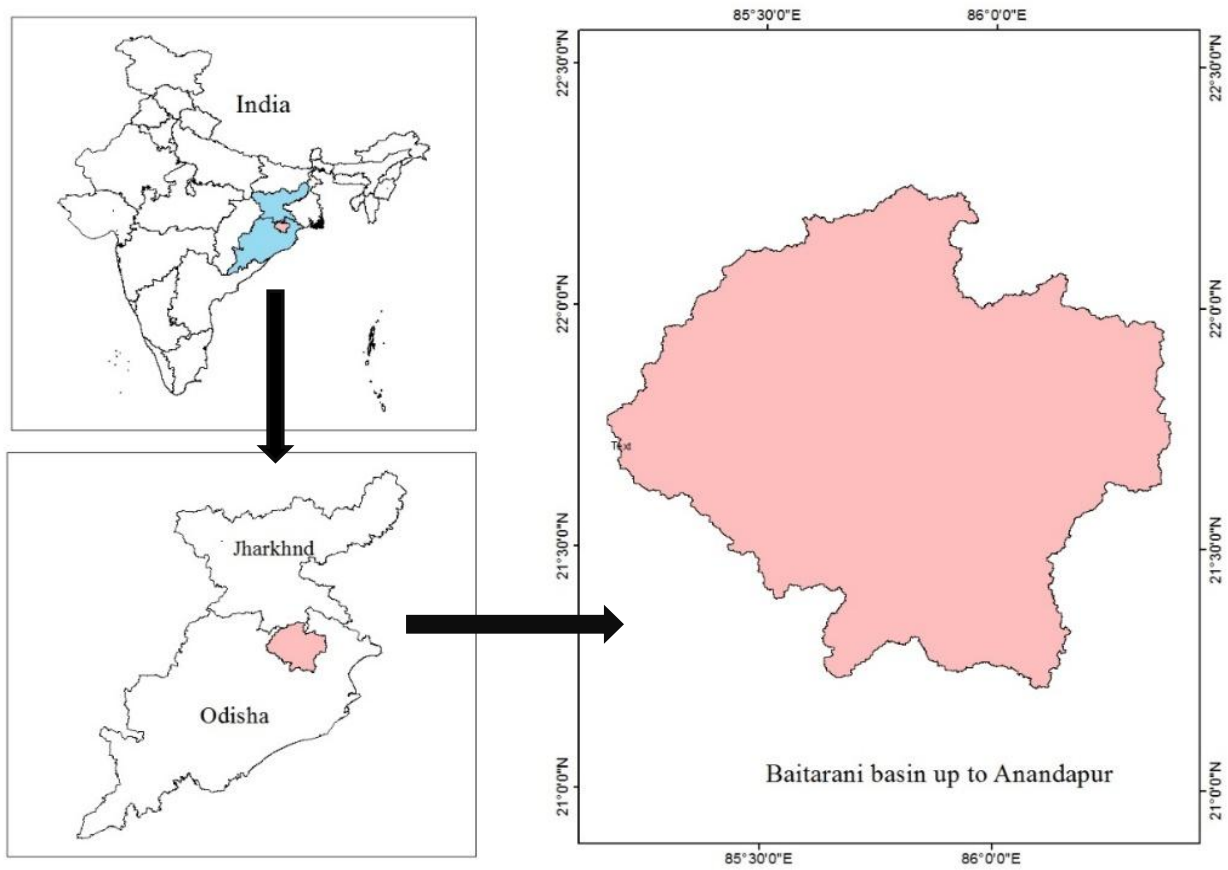


Table.4 Morphometric parameters of study area

\begin{tabular}{|c|c|}
\hline Morphometric parameters & Values \\
\hline Linear aspects & \multirow[b]{2}{*}{$\begin{array}{l}\text { The highest order of this Basin is } \\
5 \text { th order }\end{array}$} \\
\hline Stream order, u & \\
\hline Stream length, $L_{u}$ & $\begin{array}{l}\mathrm{L}_{1}=908.5 \mathrm{~km} \\
\mathrm{~L}_{2}=464.3 \mathrm{~km} \\
\mathrm{~L}_{3}=300.3 \mathrm{~km} \\
\mathrm{~L}_{4}=108.3 \mathrm{~km} \\
\mathrm{~L}_{5}=106.5 \mathrm{~km}\end{array}$ \\
\hline Stream number, $\mathbf{N}_{\mathbf{u}}$ & $\begin{array}{l}\mathrm{N}_{1}=270 \\
\mathrm{~N}_{2}=58 \\
\mathrm{~N}_{3}=13 \\
\mathrm{~N}_{4}=2 \\
\mathrm{~N}_{5}=1\end{array}$ \\
\hline Bifurcation Ratio, $\mathbf{R}_{b}$ & $\begin{array}{l}\mathrm{R}_{\mathrm{b} 1}=4.65 \\
\mathrm{R}_{\mathrm{b} 2}=4.46 \\
\mathrm{R}_{\mathrm{b} 3}=6.5 \\
\mathrm{R}_{\mathrm{b} 4}=2\end{array}$ \\
\hline $\begin{array}{l}\text { Mean bifurcation Ratio, } \\
\mathbf{R}_{\text {bm }}\end{array}$ & $\mathrm{R}_{\mathrm{bm}}=4.4$ \\
\hline Stream length ratio, $\mathbf{R}_{\mathrm{L}}$ & $\begin{array}{l}\mathrm{R}_{\mathrm{L} 2}=0.51 \\
\mathrm{R}_{\mathrm{L} 3}=0.64 \\
\mathrm{R}_{\mathrm{L} 4}=0.36 \\
\mathrm{R}_{\mathrm{L} 5}=0.98\end{array}$ \\
\hline Areal aspects & \multirow{2}{*}{$\mathrm{D}=0.219 \mathrm{~km} / \mathrm{km}^{2}$} \\
\hline Drainage density, D & \\
\hline Stream Frequency, $\mathbf{F}_{\mathrm{s}}$ & $\mathrm{F}_{\mathrm{s}}=0.039 \mathrm{~km}^{-2}$ \\
\hline Drainage Texture, $R_{t}$ & $\mathrm{R}_{\mathrm{t}}=0.409 \mathrm{~km}^{-1}$ \\
\hline Elongation Ratio, $\mathbf{R}_{\mathrm{e}}$ & $\mathrm{R}_{\mathrm{e}}=0.465$ \\
\hline Circularity ratio, $\mathbf{R}_{\mathrm{c}}$ & $\mathrm{R}_{\mathrm{c}}=0.152$ \\
\hline Form factor, $F_{f}$ & $F_{f}=0.17$ \\
\hline Length of overland flow, $\mathrm{L}_{\mathrm{g}}$ & $\mathrm{L}_{\mathrm{g}}=2.28 \mathrm{~km}$ \\
\hline $\begin{array}{l}\text { Channel } \\
\text { Factor, } \mathbf{C}_{\mathbf{m}}\end{array}$ & $\mathrm{C}_{\mathrm{m}}=4.56 \mathrm{~km}$ \\
\hline Relief aspects & \multirow[b]{2}{*}{$\mathrm{H}=1.18 \mathrm{~km}$} \\
\hline Basin relief, $\mathbf{H}$ & \\
\hline Relief ratio, $\mathbf{R}_{\mathbf{h}}$ & $\mathrm{R}_{\mathrm{h}}=0.0052$ \\
\hline Relative relief, $R_{p}$ & $\mathrm{R}_{\mathrm{p}}=0.0014$ \\
\hline Ruggedness Number, $\mathbf{R}_{\mathbf{n}}$ & $\mathrm{R}_{\mathrm{n}}=0.258$ \\
\hline
\end{tabular}


Fig.2 Stream network map of the study area

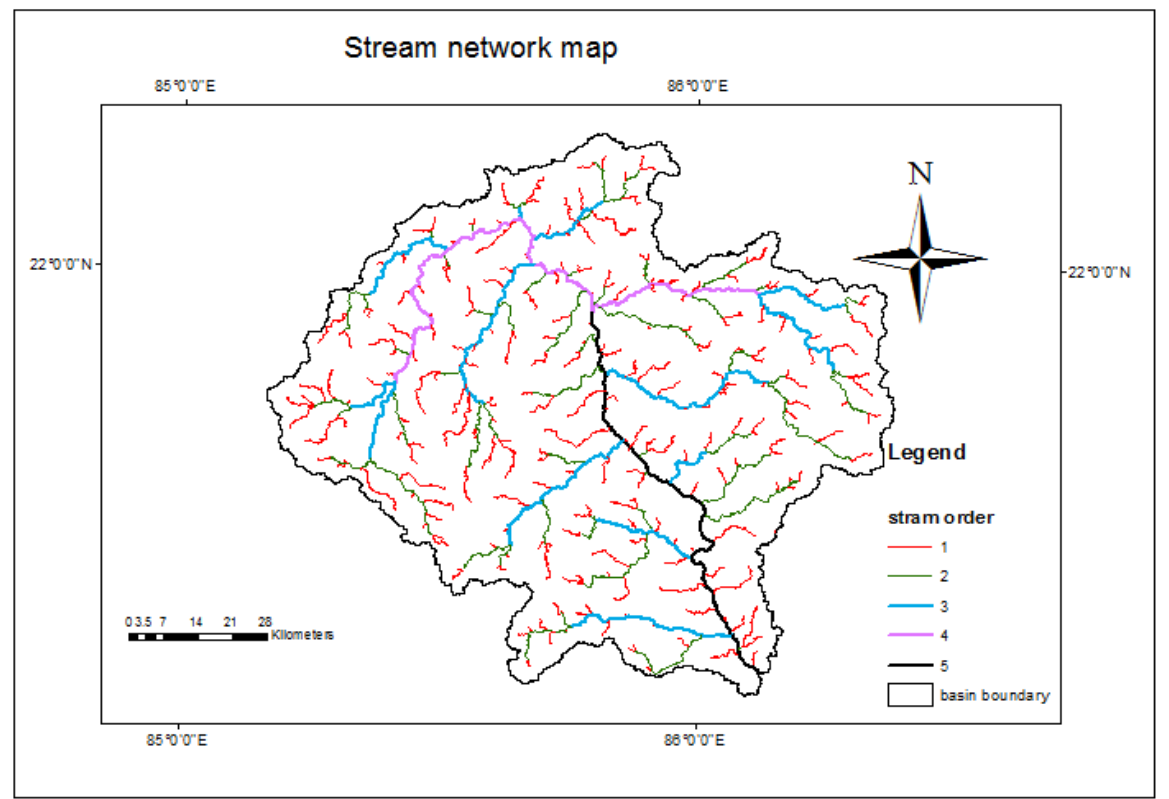

\section{Drainage texture $\left(\mathbf{R}_{\mathbf{t}}\right)$}

Drainage texture of the study area is $0.409 \mathrm{~km}^{-}$ 1 as shown in Table 4. It indicates the closeness of the spacing of channels (Horton, 1932). According to Smith, (1950), the drainage texture depends upon a number of natural factors such as climate, rainfall, infiltration capacity, rock and soil type, relief, vegetation and stage of development. Based on the classification by Smith (1950) drainage texture value 0-4 indicate coarse, 4-10 indicate intermediate, $10-15$ indicate fine and $>15$ indicate ultra-fine. So the study area has coarse drainage structure since the value of drainage structure is $0.409 \mathrm{~km}^{-1}$.

\section{Elongation ratio $\left(\mathbf{R}_{\mathbf{e}}\right)$}

Elongation ratio is a very significant index in the analysis of watershed shape which helps to give information about the hydrological character of a basin (Vinoth et al., 2014). The values of elongation ratios can be grouped into four categories namely (a) circular (>0.9), (b) oval (0.9 to 0.8$)$, (c) elongated ( 0.8 to 0.7$)$ and (d) less elongated $(<0.7)$
(Choudhari et al., 2014). The study area had elongation ratio 0.465 which is considered as less elongated type.

\section{Circularity ratio $\left(\mathbf{R}_{\mathbf{c}}\right)$}

It indicates the stage of dissection in the study area. Its low, medium and high values are correlated with youth, mature and old stage of the cycle of the tributary of watershed, respectively (Aravinda and Balakrishna, 2013). The circulatory ratio is found to be 0.152 .

\section{Form factor $\left(\mathbf{F}_{\mathbf{f}}\right.$}

It is the numerical index normally used to represent different basin shapes, with values to range from (0.1 to 0.8) (Thronbury, 1966) and it indicates the flow intensity of a basin. If the form factor value is 0.7854 then it represents a perfectly circular basin (Choudhari et al., 2014), if it is nearer to 0 indicates a highly elongated shape and the value that is closer to lindicates circular shape. Form factor of the basin is 0.17 which is shown in Table 4. 


\section{Length of overland flow $\left(\mathrm{L}_{\mathrm{g}}\right)$}

Generally higher value of length of overland flow is indicative of low relief, whereas low value is an indicative of high relief (Kanth and Hassan, 2012).

The watershed having length of overland flow greater than $0.25 \mathrm{~km}$ are under very less structural disturbance because of low runoff and higher overland flow (Patil et al., 2015). The study area has length of overland flow as $2.28 \mathrm{~km}$.

\section{Channel maintenance factor, $C_{m}$}

Channel maintenance factor depends on climatic regime, vegetation, rock type, permeability, relief, duration of erosion and climatic history. As shown in table the channel Maintenance Factor of the basin is found to be $4.56 \mathrm{~km}$.

\section{Relief aspects}

\section{Basin relief $(\mathbf{H})$}

According to Patil et al., (2015) area is of low relief region if the relief is less than $0.3 \mathrm{~km}$ and high relief region if it is greater than $0.3 \mathrm{~km}$. The high relief value indicates high gravity of water flow as well as infiltration into the ground and high runoff conditions (Patil et al., 2015). In the present study the basin relief is calculated to be $1.18 \mathrm{~km}$ which shows the basin has high relief region.

\section{Relief ratio $\left(\mathbf{R}_{h}\right)$}

Relief ratio is not only the indicator of overall steepness of the watershed but also it is the indicator of the intensity of erosion process operating at the watershed slopes (Suresh, 2012). The relief ratio of the basin is calculated to be 0.0052 which is shown in Table 4.

\section{Relative relief $\left(\mathbf{R}_{\mathbf{P}}\right)$}

Relative relief shows the terrain characteristics of the watershed. It is related to basin relief. Relative relief of the drainage basin is found to be 0.0014

\section{Ruggedness number $\left(\mathbf{R}_{\mathbf{n}}\right)$}

The ruggedness number of the study area is calculated to be 0.258.Low ruggedness value i.e. 258 of basin implies that area is less prone to soil erosion and have intrinsic structural complexity with relief and drainage density (Pareta and Pareta, 2012)

The highest order stream of the area is found to be 5 th order. The stream numbers of $1^{\text {st }}$, $2^{\text {nd }}, 3^{\text {rd }}, 4^{\text {th }}$ and $5^{\text {th }}$ order streams are found to be $270,58,13,2$ and 1, respectively. Stream length for $1^{\text {st }}, 2^{\text {nd }}, 3^{\text {rd }}, 4^{\text {th }}$ and $5^{\text {th }}$ order streams are found to be 908.5, 464.3, 300.3, 108.3 and $106.5 \mathrm{~km}$, respectively. The stream length ratios are found to be $0.51,0.64,0.36$ and 0.98 for $2^{\text {nd }}, 3^{\text {rd }}, 4^{\text {th }}$ and 5 th order streams, respectively. The mean bifurcation ratio and length of overland flow of the study area are found to be 4.4 and 2.28 , respectively which indicates a high surface runoff in the basin and late youth stage of geomorphic development of the basin. The drainage density, stream frequency and drainage texture are calculated as $0.219 \mathrm{~km} / \mathrm{km}^{2}, 0.039$ $\mathrm{km}^{-2}$ and $0.409 \mathrm{~km}^{-1}$, respectively. The study area has elongation ratio 0.465 which is considered as less elongated type. The circulatory ratio and form factor are found to be 0.152 and 0.17 , respectively. Ruggedness value is observed to be 0.258 . From this analysis it is concluded that the watershed is less elongated which result in high peak of runoff.

\section{References}

Afreeda, V. and Kannan, B. 2018. Determination of Watershed 
Morphological Parameters Using Remote Sensing and GIS. International Journal of Engineering Science and Computing. 8(3).

Anonymous. 2011. Assessment of Water Resources at Basin Scale using Space Input. A Pilot Study by NRSC and CWC. Hyderabad, India

Aravinda, P.T. and Balakrishna, H.B. 2013. Morphometric analysis of Vrishabhavathi Watershed using Remote Sensing and GIS. International Journal of Research in Engineering and Technology. 2(8), 514-522.

Barber, M. D. 2005. Hydrogeomorphology Fundamental Applications and Techniques. New India Publishing Agency, New Delhi. pp.259

Bowlekar, P., Sawant, H.B., Nandgude, S.B. and. Mahale, D.M. 2019. Morphometric Analysis of Morna River Catchment using Geographic Information System. Agricultural Engineering Today.

Chopra, R., Dhiman, R.D. and Sharma, P.K. 2005. Morphometric analysis of subwatersheds in Gurudaspur district, Punjab using Remote sensing and GIS techniques. Journal of the Indian Society of Remote Sensing. 33(4): 531539.

Choudhari, K., Panigrahi, B. and Paul, J. C. 2014. Morphometric analysis of Kharlikani watershed in Odisha, India using spatial information technology. International Journal of Geomatics and Geosciences. 4(4).

Clarke, J. I. 1996. Morphometry from Maps. Essays in Geomorphology. pp 274, Elsevier Publication. Co., New York.

Gajbhiye, S. 2015. Morphometric Analysis of a Shakkar River Catchment Using RS and GIS. International Journal of $\mathrm{u}-$ and e- Service, Science and Technology. 8(2): 11-24.

H. P. 1998. CWC studies on Brahmani and Baitarani. Hydrology Project.
Horton, R. 1932. Drainage basin characteristics. Transactions. American Geophysical Union. 13 (1): 350-361.

Horton, R. E. 1945. Erosional development of streams and their drainage basins Hydrophysical approach to Quantitative Morphology, Bulletin of Geological Society of America.56: 276-370.

Julia, K. P., Osorio, J., Wolfe, M. L., Heatwole, C., Benham, B. and Cardenas, A. 2007. Comparison of watershed boundaries derived from SRTM and ASTER digital elevation datasets and from a digitized topographic map. An ASABE Meeting Presentation Paper Number: 072093

Kanth, T. A., and Hassan, Z. 2012. Morphometric analysis and prioritization of watersheds for soil and water resource management in Wular catchment using geo-spatial tools. International Journal of Geology, Earth and Environmental Sciences. 2(1): 3041

Kushwaha, N. L., Bhardwaj, A. and Verma, V. K. 2016. Hydrologic Response of Takarla-Ballowal Watershed in Shivalik Foot-Hills Based on Morphometric Analysis Using Remote Sensing and GIS. Journal of Indian Water Resources. 36(1).

Magesh, N. S., Chandrasekar, N. and Soundranayagam, J. P. 2012. Delineation of groundwater potential zones in Theni district, Tamil Nadu, using remote sensing, GIS and MIF techniques. Geoscience Frontiers. 3(2): 189-196.

Melton, M. A. 1958. Correlating structure of morphometric properties of drainage system and their controlling agents. The Journal of Geology. 66(4): 442-460

Miller, V. C. 1953. A quantitative geomorphic study of drainage basin characteristics on the Clinch mountain area, Virgina and Tennessee. Columbia 
University. Department of Geology. ONR, New York. 389-402.

Moharir, K. N. and Pande, C. B. 2014. Analysis of morphometric parameters using remote sensing and GIS techniques in the LonarNala, Akola District, Maharashtra, India. International Journal for Technological Research in Engineering. 1(10), 10341040.

Pareta, K. and Pareta, U. 2012. Quantitative Morphometric Analysis of A Watershed: Based on digital terrain Model and GIS. LAP Lambert Academic Publishing. Germany.

Patil, N. P., Kadale, A. S. and Mhetre, G. S.2015. Assessment of Morphometric Characteristics of KarwadiNandapur Micro Watershed Using Remote Sensing and Geographical Information System. International Journal of Scientific \& Technology Research. 4(4). Paulinus, U. U., Ifedilichukwu, N.G., Ahamefula, A. C., Iheanyichukwu, O. A., Theophilus, E. T. and Edet, I.G. 2016. Morphometric analysis of Subwatersheds in Oguta and Environs, Southeastern Nigeria using GIS and Remote Sensing data. Journal of Geosciences and Geomatics. 4(2): 2128.

Pingale, S.M., Chandra, H., Sharma, H.C., Mishra, S.S. 2012. Morphometric analysis of Maun watershed in TehriGarhwal district of Uttarakhand using GIS. International Journal of Geomatics and Geoscience. 3(2): 373-784

Pophare, A. M. and Balpande, U.S. 2014. Morphometric analysis of Suketi river basin, Himachal Himalaya, India. Journal of Earth System Science. 1237:1501-1515.

Raju, K. S. and Kumar, D. N. 2011. Classification of Microwatersheds based on Morphological Characteristics. Journal of Hydro-environment
Research.5:101-109.

Satish, K. and Vajrappa, H.C. 2014. Morphological Parameter Estimation Derived From ASTER-DEM Using GIS and Remote Sensing Techniques - A Study on Hosakote Watershed of DakshinaPinakini River Basin, Karnataka, India. International Journal of Research. 1(10): 2348-6848.

Schumm, S.A. 1956. Evolution of drainage systems and slopes in Badlands at Perth Amboy, New Jersey. Geological Society of America Bulletin. 67(5), 597-646.

Sethupathi, A.S., Lakshmi, N.C., Vasanthamohan, V. and Mohan, S.P. 2011. Prioritization of mini watersheds based on morpho- metric analysis using remote sensing and gis in a drought prone BargurMathur Sub Watersheds, Ponnaiyar River Basin, India. International Journal of Geomatics and Geosciences. 2(2): 403-414.

Sharma, S. A. 2014. Morphometrical analysis of Imphal River basin using GIS. International Journal of Geology, Earth and Environmental Sciences. 4(2): 138144

Singh, P., Thakur, J. K. and Singh, U. C. 2013. Morphometric analysis of Morar river basin Madhya Pradesh India using remote sensing and GIS techniques. Environmental Earth Science. 68: 196777.

Singh, S. 1992. Quantitative geomorphology of the drainage basin. In: Chauhan TS, Joshi KN (eds) Readings on remote sensing applications. Scientific Publishers, Jodhpur

Singh, S. 1994. Remote sensing in the evaluation of morpho-hydrological characteristics of the drainage basins of the lojri catchment. Annals of Arid Zone. 33: 273-278.

Singh, S. and Singh, M. C. 1997. Morphometric Analysis of Kanhar 
River Basin. National Geographical Journal of India. 43(1): 31-43.

Smith, K. G. 1950. Standards for grading textures of erosional topography. American Journal of Science. 248(9): 655-668

Strahler, A. N. 1957. Quantitative Analysis of Watershed Geomorphology. Transactions American Geophysical Union. 38: 913-920.

Strahler, A. N. 1964. Quantitative geomorphology of drainage basins and channel networks In: Chow V T (ed) Handbook Applied Hydrology, McGraw-Hill Book Company New York, 4-11.

Suresh, R. 2012. Soil and water conservation engineering. Standard Publishers Distributors. Delhi. PP: 793-812.

Sutariya, P., Mujumdar, S. and Sena, D. 2015. Morphometric Analysis of Dhadhar River Basin, Gujarat. Journal of Indian Water Resources Society. 35(2).

Thronbury. 1966. Principles of geomorphology. 10th print, John Wiley and Sons, Inc. New York, p. 618.

Vinoth, M., Suresh, M. and Gurugnanam, B. 2014. Characteristics of drainage morphological studies using GIS in Kolli Hills, Central of Tamil Nadu, India. International Journal of Remote Sensing and Geosciences. 3(3): 10-15

\section{How to cite this article:}

Sahoo, N., B. Panigrahi, J.C. Paul and Behera, B.P. 2019. Assessment of Morphometric Parameters in Baitarani Basin using Remote Sensing and GIS. Int.J.Curr.Microbiol.App.Sci. 8(08): 2005-2018. doi: https://doi.org/10.20546/ijcmas.2019.808.234 